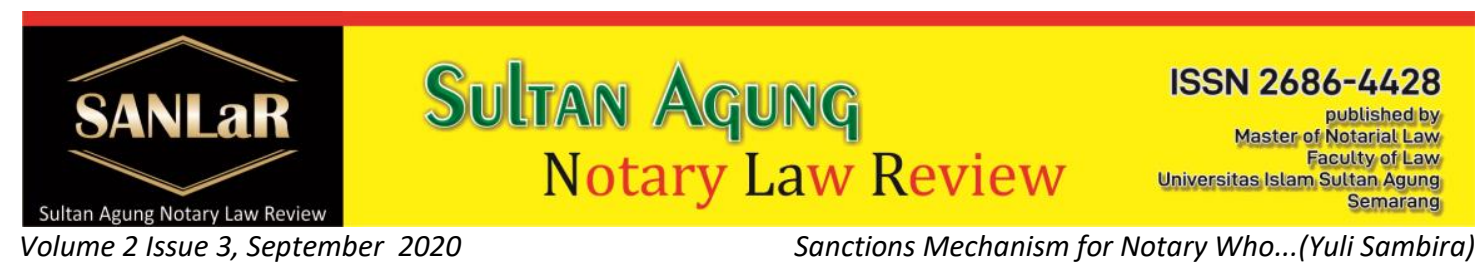

\title{
Sanctions Mechanism for Notary Who Break the Code of Ethics
}

\author{
Yuli Sambira*) \\ *) Student of Master of Notary Law, Faculty of Law, Universitas Islam Sultan Agung \\ (UNISSULA) Semarang, E-mail: yuli.sambira7@gmail.com
}

\begin{abstract}
Notary is a public official who is appointed by the Government and entrusted with the authority to make a written deed in the form of an authentic deed. Not only do notaries have the task of making authentic deeds in certain fields, but in almost every field of civil law where the Notary is authorized to make them. In carrying out his position, a notary is demanded to be more sensitive, honest, fair and transparent in order to ensure the implementation of the goals and obligations of all parties directly involved in making authentic deeds. In carrying out his/her duties, a notary must adhere to the code of ethics of the notary's office, because without it his professional dignity will be lost and he will not gain the trust of the public. The Notary Code of Ethics is a self-control for Notaries in carrying out their duties. The scope of the Notary Code of Ethics applies to all Notaries or those who hold and carry out a Notary position. The Indonesian Notary Association as the parent association for Notaries, has a very important role in enforcing the implementation of the Professional Code of Ethics for Notaries. In upholding the Code of Ethics, there must be harmony between the Notary concerned, professional colleagues, the community and professional organizations, in this case the Indonesian Notary Association, through the Honorary Council which has the main task of supervising the implementation of the Code of Ethics.
\end{abstract}

Keywords: Sanctions; Notary; Ethics.

\section{Introduction}

The Notary Institution was founded in Indonesia since 1860, so the Notary Institution is not a new institution in the community ${ }^{1}$. The position of notary is an office whose existence is desired by the state in relation to the goal of realizing legal certainty in the traffic of civil interactions.

The notion of a notary is contained in Article 1 number 1 of Act No. 2 of 2014 concerning Amendments to Act No. 30 of 2004 concerning the Position of a Notary. Notaries are:

"Public officials who are authorized to make authentic deeds and have other powers as referred to in this Law or other Laws".

\footnotetext{
${ }^{1}$ Soekanto, Soerjono \& Purnadi Purbacaraka. (1993). Sendi-Sendi Ilmu Hukum da Tata Hukum. Bandung: Citra Aditya Bakti.p. 63
} 
The main task of the Notary is to make authentic deeds, the Notary in carrying out his duties and powers to make deeds which are requested by the parties facing him, the Notary must fulfill 4 (four) elements, namely:
a. The Element of Truth,
b. Elements of Validity,
c. Completeness Elements,
d. The Element of Clarity.

Notaries in exercising their authority are bound by the provisions that must be obeyed, as stated in Article 15 of Act No. 30 of 2004 concerning the Position of Notary Public, which among other things states ${ }^{2}$ :

a. The notary is authorized to make authentic deeds regarding all deeds, agreements, and provisions required by laws and regulations and/or those interested in being stated in the authentic deed, guarantees the certainty of the deed creation date, keeps the deed of giving grosse, copies and excerpts of the deed, all Insofar as the making of the deeds is not assigned or excluded from other officials or other persons determined by law.

b. The notary is also authorized:

1) Validate the signature and set the date certainty of the letter under the hand by registering in a special book.

2) Book letters under hand by registering in a special book;

3) Make a copy of the original letters under hand in the form of a copy containing the description as written and described in the letter concerned.

4) Conduct validation of the compatibility of the photocopy with the original letter.

5) Providing legal education in connection with making deeds.

6) Making deeds related to land;

7) Prepare a deed of auction minutes

The authority of a notary can be constructed as: "The power granted by law to a notary to make authentic deeds or other powers." 3 Other powers are those that have been determined in statutory regulations which were subsequently made by Habib Adjie ${ }^{4}$ divided into 3 (three) domains:

a. The authority is the general authority of the Notary (Article 15 paragraph (1) UUJN), Act No. 30 of 2004 as amended by Act No. 2 of 2014 concerning the Position of Notary Public, these powers are:

\footnotetext{
2 Staatblad 1860 Number 3 Concerning the Regulation of Notary Position in Indonesia

${ }^{3}$ Salim Hs. (2015). Teknik Pembuatan Akta (Konsep Teoritis, Kewenangan Notaris, Bentuk Dan Minuta Akta). Jakarta: Radja Grafindo.p. 49

${ }^{4}$ Adjie, Habib. (2007). Hukum Notaris Indonesia, Tafsir Tematik Terhadap Undang-Undang Nomor 30 Tahun2004 Tentang Jabatan Notaris. Surabaya: Refika Aditama. p.80
} 
"Notaries have the authority to make authentic deeds regarding all actions, agreements, and regulations that must be required by the laws and regulations and/or that the interested party wants to be stated in the authentic deed. Guarantee the certainty of making the date of the deed, keeping the deed, making grosse, copy and excerpt of the deed, all that as long as the deed is made or not assigned or excluded to other officials or other people stipulated by law.

Based on the authority that is in the Notary Public as stated in Article 15 UUJN and the evidentiary power of the Notary deed, 2 (two) conclusions can be drawn:

b. The task of the notary is to formulate the wishes/actions of the parties into an authentic deed by taking into account and not violating applicable legal provisions. ${ }^{5}$.

c. Authentic deed which has perfect legal force of proof and is binding for the parties so that in the proof it can stand alone and there is no need for assistance and additional from other evidence. If any opposing party can prove that the deed is incorrect with other authentic deeds, then sometimes the proof of other authentic deeds can be reduced, so it is necessary to obtain the help of other evidence.

Besides having the authority as mentioned above, the Notary in carrying out his duties and positions as a public official also has several obligations and prohibitions that must be carried out by the Notary as regulated by UUJN.

The definition of obligations according to the Notary Code of Ethics is the attitude of behavior or actions that must or must be carried out by members of the association or other people who hold and carry out the Notary Office, in order to maintain and maintain the image and authority of the notary institution and uphold the dignity and dignity of the notary office. ${ }^{6}$. This is in accordance with the provisions of Article 16 paragraph (1) UUJN amendment which states that in carrying out his/her position, Notary Public is obliged to:

a. Acting trustworthy, honest, thorough, independent and impartial, and safeguarding the interests of the parties involved in their legal actions;

b. Make deeds in the form of Minuta Deed and keep them as part of the Notary Protocol

c. Attaching letters and documents and fingerprints of the applicants to the Minuta Deed

d. Issuing Grosse Deed, Copy of Deed and Quotation of Deed based on Minuta Deed

e. Providing services in accordance with the provisions of this Law, unless there is a reason to refuse it

f. Keep everything about the deed he has made and all information obtained in order to make the deed in accordance with the oath/promise of office, unless the law stipulates otherwise

\footnotetext{
${ }^{5}$ Ibid.

${ }^{6}$ Saputra, D., \& Wahyuningsih, S. E. (2017). Prinsip Kehati-Hatian Bagi Notaris/Ppat Dalam Menjalankan Tupoksinya Dalam Upaya Pencegahan Kriminalisasi Berdasarkan Kode Etik. Jurnal Akta, 4 (3), 347-354.
} 
g. Binding the deeds that he makes in 1 (one) month into a book containing no more than 50 deeds and if the deeds are not contained in one book, these deeds can be bound into more than one book, and record the Minuta Deed number, month and year of manufacture on the cover every book

h. Make a list of deeds of protest against non-payment or non-receipt of securities

i. Make a list of deeds approved by the will according to the time sequence of the deeds making each month

j. Send the list of deeds as referred to in letter I or the nil list relating to will to the center of the will of the ministry that administers government affairs in the field of law within 5 (five) days in the first week of each following month.

k. Record in the peretorium the date of delivery of the testament at the end of each month.

I. Has a stamp or seal bearing the symbol of the Republic of Indonesia and in the space surrounding it is written the name, position and domicile of the person concerned

$\mathrm{m}$. Read out the deed in front of the audience in the presence of at least 2 (two) witnesses or 4 (four) special witnesses for the making of the will under hand and signed on the spot by the tappers, witnesses and notaries

n. Receiving internship for prospective Notaries.

Notaries as public officials have the authority, namely to make authentic deeds and other deeds. The authentic deed must be correct and in accordance with the prevailing laws and regulations. In exercising his authority, he is not allowed to exercise his authority outside the area of his office, may not hold concurrent positions, and so on. If this is done by a notary, then he is qualified to violate the prohibitions stated in the law. The act that is done is a prohibition for the notary.

There are several things that are prohibited or justified for a Notary to do so when carrying out the duties and positions of a Notary according to the UUJN, which are as follows:

a. Carry out his position outside the area of his position

b. Leaving his/her position of office for more than 7 (seven) consecutive working days for no apparent reason

c. Concurrently as a civil servant

d. Concurrently serving as a State official

e. Concurrently serving as an advocate

f. Concurrently serving as a leader or as an employee of a state-owned company, regional-owned company or private-owned company.

g. Concurrently holding positions as Land Deed Making Official outside the notary's office area

h. Become a substitute notary.

i. Doing other work that is contrary to religious norms, morals or propriety which may affect the honor and dignity of the notary's office. 
Notary's code of ethics is a provision that is determined and enforced by the Notary Organization as written in Article 83 Paragraph (1) of Act No. 30 of 2004 concerning Notary Office which reads: "Notary Organization establishes and enforces the Notary Code of Ethics." Where these provisions are the basis for the Notary in carrying out his position. As stated in the Oath of Position of Notary in Article 4 which reads: "That I will maintain my attitude, behavior, and will carry out my obligations. In accordance with the code of professional ethics, honor, dignity, and my responsibility as a Notary. "

Every profession that is run with good moral values by implementing a code of ethics in that profession. This profession will have a solid foundation to gain broad trust from the community. The notary profession is based on moral values, so that his work must be based on obligations, that is, there is a good will in himself, not depending on the goals or results achieved. The moral attitude that supports the Notary's professional ethics is to act on the basis of determination, awareness of the obligation to lead professional ethics, creating idealism to job practice, namely working not for profit, serving others, so the relationship between ethics and morals is that ethics is a critical reflection of morality issues,

The existence of a code of ethics aims to make a profession run with moral/dignity, motivation and orientation to intellectual skills as well as argue rationally and critically and uphold moral values. With a code of ethics, public trust in a profession can be strengthened, because every client has certainty that his interests will be guaranteed. Professional codes of ethics are also important as a means of social control.

\section{Research and Methods}

This research method uses normative juridical research by conducting library research to obtain secondary data. The results of this research will be presented in a descriptive analyst report ${ }^{7}$. The data collection techniques for legal research include literature research studies to obtain secondary legal materials in order to obtain a theoretical basis in the form of expert opinions and also to obtain information in the form of formal provisions and data through official texts or legal materials in the form of applicable laws and regulations, journals and other to be discussed in this research.

\section{Results and Discussion}

\subsection{Mechanism for Imposing Sanctions against Notaries Who Violate the Code of Ethics}

The Indonesian Notary Association (INI) in an effort to maintain the honor and nobility of the notary office, has a notary code of ethics established by congress and is a moral code that must be adhered to by every member of INI. The Honorary Council is an

\footnotetext{
7 Pahlevi, K., Prananingtyas, P., \& Lestari, S. N. (2017). Analisis Yuridis Terhadap Penggunaan Saham Pinjam Nama (Nominee Arrangement) Ditinjau Dari Peraturan Perundang-Undangan Di Indonesia. Diponegoro Law Journal, 6 (1), 1-19.
} 
organ of INI equipment consisting of members elected from INI members, who are highly dedicated and loyal to the association, have good personalities, are wise and wise, so that they can become role models for members and are appointed by the congress for a term equal to the tenure of the management.

The Honorary Council has the authority to examine violations of the code of ethics and impose sanctions on the violators in accordance with its authority and has the duty to:

a. Carry out coaching, guidance, supervision, and arrangement of members in upholding the code of ethics;

b. Checking and making decisions on suspected violations of the provisions of the code of ethics that are internal or that do not have a direct relationship with the community;

c. Provide suggestions and opinions to the supervisory panel for suspected violations of the code of ethics and the position of notary public.

This Regional Management has a Regional Honorary Council in every management of the Regional Management of the Indonesian Notary Association. Regional Honorary Councils are bodies that are autonomous in making decisions that have the duty and obligation to provide guidance and supervise the implementation and compliance of the code of ethics by association members in their respective regions.

The Regional Honorary Council consists of 3 (three) members including a Chairman, a Deputy Chairperson and a Secretary. Those who can be appointed as members of the Regional Honorary Council are ordinary members who have served as notaries for at least 5 (five) years and extraordinary members (former notaries), who always comply with the association's regulations and applicable laws and regulations, are highly dedicated, and loyal and have a high sense of concern for regional conferences can determine other things, especially regarding the composition of notaries and former notaries. The term of office of the Regional Honorary Council is the same as the term of office of a member of the Regional Executive ${ }^{8}$.

The Regional Honorary Council is an autonomous body in making decisions which has the duty and obligation to provide guidance from supervising the implementation and compliance of the code of ethics by association members in their respective regions. In the framework of carrying out its duties and obligations the Regional Honorary Council has the authority to:

a. Provide and submit suggestions and suggestions related to the code of ethics and fostering a sense of professional togetherness (corpsgeest) to Regional Administrators;

\footnotetext{
8 Jamil, M. (2018). Sanksi Pelanggaran Kode Etik Notaris Oleh Majelis Pengawas Daerah. Supremasi Hukum: Jurnal Kajian Ilmu Hukum. p.7 (2)
} 
b. Give warnings, either in writing or orally, directly to members in their respective regions who commit violations or commit acts that are not in accordance with the code of ethics or are contrary to the sense of togetherness in the profession;

c. Notifying of the violation to the Regional Administrators, Regional Administrators, Regional Honorary Councils, Central Administrators and Central Honorary Councils;

d. Propose to the Central Executive through the Regional Honorary Council and the Central Honorary Council for the temporary dismissal (schorsing) of association members who violate the code of ethics.

The point of examination and imposition of sanctions is that the Regional Supervisory Council or commonly abbreviated as MPD will examine Notaries regarding the problems of recording deed numbers to the Notary's Reportorium, where there are facts of suspected violations. According to Article 8 of the 2015 Notary Code of Ethics as follows:

a. The Regional Honorary Council/Regional Honorary Council/Central Honorary Council can seek facts on the alleged violation of the Code of Ethics by association members on their own initiative or after receiving a written complaint from an association member or other person accompanied by convincing evidence that there has been a violation of the code of ethics. by association members,

b. Violation or receipt of complaints that have been examined by an honorary council, may no longer be examined by another Honorary Council.

Imposing sanctions according to the Notary Code of Ethics Article 9 of 2016, namely the Regional Honorary Council, the Regional Honorary Council and the Central Honorary Council, after discovering the facts of the violation of the code of ethics, as referred to in Article 8 above, within 14 working days Honor who inspects is obliged to summon the member concerned in writing to ensure a violation of the code of ethics by members of the association and to give the person the opportunity to provide an explanation and defense based on the results of the examination, an examination report signed by the member concerned and the Honorary Council examining it, in the event that the member concerned is not willing to sign the official report, it is sufficient for it to be signed by the examining Honorary Council.

The Honorary Council examining, no later than 30 (thirty) working days after the date of the last trial, is obliged to make a decision on the results of the examination as well as determine sanctions for violations if it is proven that there is a violation as regulated in the provisions of Article 6 of the Code of Conduct as outlined in decree. If the member concerned is not proven to have committed a violation, the member will be reinstated by a Decree of the Honorary Council that examined it. The examining honor council is obliged to send the decree to the member being examined by means of a registered letter and copies thereof to the Central Executive, Central Honorary Council, Regional Administrators, Regional Honorary Councils, Regional Administrators and Regional Honorary Councils. 
In handling or resolving a case, a member of the Regional Honorary Council must ${ }^{9}$ :

a. Keep respecting and upholding the dignity concerned;

b. Always maintain a family atmosphere;

c. Keep everything it finds a secret.

For Notaries who violate the code of ethics, the Honorary Council in coordination with the Supervisory Board has the authority to examine the violation and can impose sanctions on the violators, the sanctions imposed on members of the Indonesian Notary Public Association who violate the code of ethics can be:
a. Warning;
b. Schorsing (dismissal) from membership of the Association;
c. Onzetting from membership of the Association;
d. Disrespectful dismissal of Association membership

The Honorary Council is a tool for association with the authority to examine all violations of the code of ethics that are internal or that have no direct connection with the interests of the community and impose sanctions on violators in accordance with their authority. A member of the Indonesian Notary Public Association may be temporarily suspended from membership by the Central Executive or proposed by the Central Honorary Council, Regional Honorary Council or Regional Honorary Council through the Central Honorary Council, for committing one or more of the following acts:

a. Committing an act which constitutes a serious violation of the provisions of the articles of association, bylaws, code of ethics and legal decisions of the association;

b. Committing acts that defame, harm or demean the good name of the association;

c. Misusing the name of the association for personal gain.

If a member who is suspended based on a congressional decision is found guilty, the member concerned can be permanently dismissed from membership in the association. Based on a congressional decision, the Central Executive makes a decision to dismiss the member concerned and this decision is reported by the Central Executive to the minister in charge of the notary office, the Central Supervisory Council, the Regional Supervisory Council and the Regional Supervisory Council and other agencies which according to the Central Executive's consideration need a report. However, the dismissal sanction given to a notary who violates the code of ethics is not in the form of dismissal from the position of the Notary Public but rather dismissal from the membership of the Indonesian Notary Public so that even though the notary concerned has been proven to have violated the code of ethics, because the sanction does not mean that the notary is automatically dismissed from his position, because only the minister is authorized to dismiss the notary from his position by hearing a

\footnotetext{
9 Sulistiyono, S. Pelaksanaan Sanksi Pelanggaran Kode Etik Profesi Notaris Oleh Dewan Kehormatan Ikatan Notaris Indonesia Di Kabupaten Tangerang. Jurnal Notarius, 1 (1), p.75-100.
} 
report from the Supervisory Council. Another example is a notary who is sentenced to dismissal from the notary association for violating the code of ethics by deliberately hiring a person who is still another notary employee, he can still carry out his position, so that the sanction seems less binding for a notary who violates the code ethics. ${ }^{10}$

\subsection{Role of the Notary Supervisory Council in Guiding Notaries Who Violate the Code of Ethics}

The Notary Supervisory Council is an agency that has the authority and obligation to carry out supervision and guidance for Notaries. In accordance with the provisions of Article 67 of Act No. 2 of 2014 concerning Amendments to Law 30 of 2004 concerning the Position of Notary Public, it is stated that supervision of Notaries is carried out by the Minister by forming a Supervisory Council consisting of the Regional Supervisory Council, the Regional Supervisory Council and the Central Supervisory Council. .

Supervision of Notary Public is the implementation of the function of guidance and supervision of the implementation of the office and behavior of the Notary. This task is carried out by the Notary Supervisory Council as an extension of the Minister of Law and Human Rights of the Republic of Indonesia who has the supervisory authority over Notaries.

\section{Closing}

For Notaries who violate the code of ethics and impose sanctions on violators in accordance with their authority, the Notary Supervisory Council must provide guidance, guidance, supervision and supervision of members in upholding the notary's code of ethics. And the Indonesian Notary Association is also the parent of the association of notaries, must provide legal protection from its members in the event that its members are subject to a sanction in the form of conditional protection in the sense of providing assistance as long as the Notary who is subject to the position sanction is an active member of INI who during his membership period carries out the obligations to the organization, apart from that PP-INI also provides assistance in the form of assistance during an inspection by the Supervisory Council.

\section{References}

\section{Journals:}

[1] Pahlevi, K., Prananingtyas, P., \& Lestari, S. N. (2017). Analisis Yuridis Terhadap Penggunaan Saham Pinjam Nama (Nominee Arrangement) Ditinjau Dari Peraturan Perundang-Undangan Di Indonesia. Diponegoro Law Journal, 6 (1), 1-19.

[2] Rifa'i, A., \& Iftitah, A. (2018). Bentuk-Bentuk Pelanggaran Hukum Dalam Pelaksanaan Jabatan Notaris. Jurnal Supremasi, 8 (2), p.4

10 Rifa'i, A., \& Iftitah, A. (2018). Bentuk-Bentuk Pelanggaran Hukum Dalam Pelaksanaan Jabatan Notaris. Jurnal Supremasi, 8 (2), p.4 
[3] Saputra, D., \& Wahyuningsih, S. E. (2017). Prinsip Kehati-Hatian Bagi Notaris/Ppat Dalam Menjalankan Tupoksinya Dalam Upaya Pencegahan Kriminalisasi Berdasarkan Kode Etik. Jurnal Akta, 4 (3), 347-354.

[4] Sulistiyono, S. Pelaksanaan Sanksi Pelanggaran Kode Etik Profesi Notaris Oleh Dewan Kehormatan Ikatan Notaris Indonesia Di Kabupaten Tangerang. Jurnal Notarius, 1 (1), p.75-100.

Books:

[1] Jamil, M. (2018). Sanksi Pelanggaran Kode Etik Notaris Oleh Majelis Pengawas Daerah. Supremasi Hukum: Jurnal Kajian Ilmu Hukum

[2] Soekanto, Soerjono \& Purnadi Purbacaraka. (1993). Sendi-Sendi Ilmu Hukum da Tata Hukum. Bandung: Citra Aditya Bakti

[3] Salim Hs. (2015). Teknik Pembuatan Akta (Konsep Teoritis, Kewenangan Notaris, Bentuk Dan Minuta Akta). Jakarta: Radja Grafindo

[4] Adjie, Habib. (2007). Hukum Notaris Indonesia, Tafsir Tematik Terhadap UndangUndang Nomor 30 Tahun2004 Tentang Jabatan Notaris. Surabaya: Refika Aditama

Regulations:

[1] The Constitution of the Republic of Indonesia 1945

[2] Code of Civil law

[3] Act No. 30 of 2004

[4] Act No. 2 of 2014 concerning the Position of Notary Public

[5] Staatblad 1860 Number 3 Concerning the Regulation of Notary Position in Indonesia 